\title{
Intensitas Pola Asuh Authoritative Anak Usia Dini Yang Memiliki Ibu Tenaga Kerja Wanita Terhadap Hasil Belajar Di Sekolah Di Bajang Mlarak Ponorogo Propinsi Jawa Timur
}

\author{
Mukti Lestari ${ }^{1}$, Dyka Andrian ${ }^{2}$ \\ ${ }^{1}$ Dosen, Universitas Doktor Nugroho Magetan, Jln. Sendang Kamal No.50, Magetan, 63392 \\ E-mail: muktilestari@udn.ac.id \\ ${ }^{2}$ Dosen, Universitas Doktor Nugroho Magetan, Jln. Sendang Kamal No.50, Magetan, 63392 \\ E-mail: nuningfarida@udn.ac.id
}

\begin{abstract}
Parenting parents greatly affect the lives of children and learning outcomes obtained in school. This research is a qualitative descriptive study, where data obtained from observation, interview, and documentation. Data analysis was performed interactivity and continuously so that the data is already saturated. Activity in the data analysis include data reduction, data presentation and conclusion. From the research results can be known children who have a migrant mother still get a good upbringing from substitute caregivers and mothers with parenting autoritative TKW as not curb the freedom of children to play and learn and provide the freedom to act for positive. Learning outcomes of children whose mothers maids in Ponorogo Mlarak Bajang TK is well developed.
\end{abstract}

Keywords —: Early childhood; Mrs. Labor Women; Learning outcomes.

\section{PENDAHULUAN}

Perkembangan pada anak sangat ditentukan oleh pendidikan dan pengalaman yang dilaluinya, terutama pada masa-masa pertumbuhan yang pertama (masa anak). Pendidikan bisa diperoleh dimana saja, misalnya dalam lingkungan keluarga. Salah satu lembaga terkecil yang merupakan lingkungan pertama dikenal manusia sejak lahir adalah keluarga. Keluarga adalah kelompok yang paling awal yang dapat membentuk kepribadian, watak, dan perilaku bagi seorang anak. Seorang anak akan menjadi baik ataukah justru menjadi beban dalam masyarakat, sebagian besar merupakan refleksi dari pendidikan yang didapatkannya dalam keluarga karena perkembangan pada anak terbentuk mulai di dalam keluarga.

Peran orang tua dalam pendidikan anak sangat di butuhkan. Apabila orang tua dapat berperan semaksimal mungkin dalam mendidik anak maka akan dapat melahirkan generasi penerus yang lebih dari pada generasi kita yang ada pada saat ini. Peranan orang tua sangat dominan dalam perkembangan anak, karena berhasil tidaknya pendidikan anak merupakan tanggung jawab orang tua yang sangat berpengaruh pada pembentukan sikap dan perilaku terhadap pendidikan anak. Cara mendidik anak yang salah dapat berakibat fatal bagi kehidupan anak selanjutnya.

Orang tua wajib mendampingi dan selalu memberikan pantauan dan dukungan terhadap hasil belajar anak. Namun sayang tidak semua anak mendapat pendampingan penuh dari orang tua. Hal ini disebabkan permasalahan perekonomian dalam keluarga. Banyak orang tua terutama di daerah pedesaan yang pergi ke luar negeri menjadi TKW untuk memenuhi kebutuhan ekonominya tersebut. Keadaan demikian tentu sangat mempengaruhi pola asuh anak.

Ibu yang menjadi TKW biasanya mempercayakan pengasuhan anak kepada kelurganya seperti suami, nenek, atau keluarga dekat yang lain. Padahal dimasa pertumbuhan anak usia dini sangatlah diperlukan intensitas orang tua (ibu) dalam perkembangan belajar anak. Pada masa-masa keemasan anak usia dini ini hendaknya orang tua khusunya ibu harus memberikan stimulus-stimulus kepada anak-anak mereka.

Salah satu cara yang dapat dilakukan oleh ibu yang menjadi TKW untuk tetap bisa membimbing anak mereka untuk belajar adalah dengan menerapkan pola asuh autoritative. Dalam pola asuh autoritative ini orang tua akan mendorong anaknya untuk menjadi mandiri tetapi masih membatasi dan mengontrol tindakan anaknya. Orang tua yang menjadi TKW tersebut dapat melakukan pemantauan jarak jauh dengan selalu mengontrol hasil belajar anaknya dan disini orang tua bersikap membimbing dan mendukung apa yang diinginkan anak selama masih dalam batasan yang positif.

Selain melakukan pemantauan sendiri terhadap anak, Ibu TKW juga bisa memberikan bimbingan kepada keluarga pengasuh pengganti untuk bisa memberikan pengasuhan secara autoritative juga. Hal ini diharapkan agar anak yang ditinggal ibunya menjadi TKW tetap bisa memiliki hasil belajar yang baik. Interaksi di dalam keluarga akan berpengaruh terhadap perkembangan anak karena anggota keluarga itulah yang mengisi dalam pembentukan mental dan kepribadian anak.

Oleh karena itu berdasarkan latar belakang tersebut peneliti ingin melakukan sebuah penelitian tentang intensitas pola asuh orang tua yang ibunya menjadi TKW terhadap hasil belajar anak dengan judul "Intensitas Pola Asuh Authoritative Anak Usia Dini Yang Memiliki Ibu Tenaga Kerja Wanita Terhadap Hasil Belajar Di Sekolah Di Bajang Mlarak Ponorogo”. 
Website : http://sosial.unmermadiun.ac.id/index.php/sosial

Manfaat dari penelitian ini di harapkan dapat memberikan pengetahuan yang mendalam dan komprehensip tentang adanya pola asuh authoritave yang dilakukan orang tua selain ibu terhadap anak usia dini yang memiliki ibu tenaga kerja wanita. Para orang tua diharapkan memahami pentingnya pola asuh autoritative terhadap hasil belajar anak di sekolah.

\section{KAJIAN PUSTAKA}

\section{A. Pola Asuh Authoritative}

Perkembangan anak usia dini sangat dipengaruhi oleh pola asuh orang tua yang mana akan mempengaruhi anak usia dini dalam proses tumbuh kembang sang anak pada umunnya. Pemilihan pola asuh yang baik dan tepat juga akan menghasilkan pertumbuhan anak yang bagus dalam mencakup semua aspek kehidupan. Orang tua adalah kunci utama dalam proses perkembangan anak-anaknya. Untuk itu sangat diperlukan perhatian yang ekstra bagi anak usia dini dalam proses pengembangan diri. Orang tua yang baik adalah orang tua yang mengerti kemampuan anak dan serta bakat sang anak sejak dini, yang mana bukan berarti orang tua selalu mengikuti kemauan dan permintaan anak.

Pola asuh merupakan rangkaian sikap orang tua dalam berinteraksi, membimbing, membina, dan mendidik anak dalam kehidupannya sehari-hari dengan harapan menjadikan anak mampu menjadi sukses menjalani kehidupannya. Hal ini sejalan dengan pendapat Euis (2004:18) "Pola asuh merupakan serangkaian interaksi yang intensif, orangtua mengarahkan anak untuk memiliki kecakapan hidup".

Sedangkan (Maccoby dalam Yanti, 2005:14) mendefinisikan pola asuh sebagai interaksi orangtua dan anak-anak yang didalamnya orangtua mengekspresikan sikap-sikap atau perilaku, nilai-nilai, minat dan harapan-harapanya dalam mengasuh dan memenuhi kebutuhan anak-anaknya.

Agar potensi yang dimiliki anak dapat tumbuh dan berkembang secara optimal, ada tiga faktor yang harus diperhatikan yaitu: (1) pemeliharaan kesehatan, (2) pemberian makanan yang bergizi, dan (3) pemberian rangsangan psikososial (pendidikan), dalam bimbingan dan pengasuhan orang-orang yang professional dan kerjasama dengan orang tua serta tokoh-tokoh masyarakat. Pendidikan akan berhasil dengan baik apabila ada kerjasama antara keluarga, sekolah dan masyarakat. Apa yang diajarkan disekolah seharusnya diterapkan pula di keluarga, dan didukung oleh anggota masyarakat.

Menurut Baumrind (dalam Santrock 2002: 257-258) ada empat macam bentuk pola asuh adalah sebagai berikut:

a. Pola asuh otoriter, adalah bentuk pola asuh yang menuntut agar anak patuh dan tunduk terhadap semua perintah dan aturan yang dibuat oleh orangtua tanpa ada kebebasan untuk bertanya atau mengemukakan pendapat sendiri.

b. pola asuh autoritatif atau demokrasi, pada pola asuh ini orangtua yang mendorong anak-anaknya agar mandiri namun masih memberikan batas-batas dan pengendalian atas tindakan-tindakan mereka. Musyawarah verbal dimungkinkan dengan kehangatan-kehangatan dan kasih sayang yang diperlihatkan. Anak-anak yang hidup dalam keluarga demokratis ini memiliki kepercayaan diri, harga diri yang tinggi dan menunjuk perilaku yang terpuji.

c. Pola asuh penelantaran adalah pola asuh dimana orang tua sangat tidak terlibat dalam kehidupan anak, orangtua pada pola asuh ini mengembangkan perasaan bahwa aspek-aspek lain kehidupan orangtua lebih penting dari pada anak-anak. Dimana orangtua lebih cenderung membiarkan anak-anaknya dibesarkan tanpa kasih sayang dan pemenuhan kebutuhan fisik yang cukup.

d. Pola asuh orang tua permisif, dimana pada pola asuh ini orangtua sangat terlibat dalam kehidupan anak-anak mereka, namun menetapkan sedikit batas atau kendali terhadap anak mereka. Orangtua cenderung membiarkan anak-anak mereka melakukan apa saja, sehingga anak tidak dapat mengendalikan perilakunya serta tidak mampu untuk menaruh hormat pada orang lain.

Berdasarkan pengertian di atas maka dapat disimpulkan bahwa pola asuh orangtua adalah proses interaksi antara orangtua dengan anak dimana orangtua mencerminkan sikap dan perilakunya dalam menuntun dan mengarahkan perkembangan anak serta menjadi teladan dalam menanamkan perilaku kepada anak.

Pola asuh authoritative adalah pola asuh dimana kedudukan orangtua dan anak adalah sama, sehingga mempunyai kebebasan yang sama dalam mengutarakan pendapat masing-masing. Setiap keputusan dalam pola asuh ini diambil berdasarkan kesepakatan bersama, dan tidak ada yang merasa dihakimi. Pola asuh ini akan membentuk keharmonisan antara orangtua dan anak, karena anak merasa dirinya memiliki hak dalam mempertahankan dan memperjuangkan apa yang menurutnya benar. Pola asuh authoritative akan mendorong anak untuk belajar bertanggungjawab dengan apa yang dikatakannya namun kebebasan yang diberikan pada anak tetap dalam pengawasan orangtua, sehingga orangtua masih dengan mudah mengontrol apa yang dilakukan anak sesuai dengan tingkat-tingkat perkembangan usia anak.

Hal ini didukung oleh pendapat Gunarsa (2008:84) yang menyatakan bahwa pola asuh authoritative ini memperhatikan dan menghargai kebebasan anak, namun kebebasan yang bertanggung jawab dan dengan bimbingan secara penuh pengertian antara kedua belah pihak. Keinginan dan pendapat anak diperhatikan dan jika sesuai dengan norma-norma pada orang tua, maka disetujui untuk dilakukan. Sebaliknya, jika keinginan dan pendapatnya tidak sesuai, maka akan diberikan pengertian kepada anak secara rasional dan obyektif dengan meyakinkan perbuatannya. Jika itu baik, maka perlu dibiasakan dan jika tidak baik hendaknya tidak dilakukan kembali. 
Beberapa indikator yang tentang kepemimpinan authoritative antara lain sebagai berikut (Kayo, 2006: 62-64):

a. Menempatkan anggota keluarga dalam pandangan yang terhormat, mulia dan berpotensi. Saling menghargai tanpa membeda bedakan antar anggota keluarga yang lain. Memberi kesempatan pada anak untuk mandiri dan mengembangkan control internal.

b. Terbuka dan menerima kritik dan saran dari sesame anggota keluarga. Anak diakui sebagai pribadi oleh orang tua dan dilibatkan dalam pengambilan keputusan. Pengambilan keputusan berorientasi pada musyawarah anggota keluarga, bukan hasil pemikiran seorang anggota saja.

c. Berupaya menciptakan iklim yang kondusif dan mengutamakan kerja sama antar anggota keluarga. Menetapkan peraturan dan mengatur kehidupan anak. Memprioritaskan kepentigan anak dan tidak ragu mengendalikan mereka.

d. Mendorong anggota keluarga untuk bebas berinisiatif melalui bakat, minat dan kreatfitas yang dinamis. Lebih bersikap edukatif kepada anak dan Bersikap realistis terhadap kemampuan anak.

e. Memberikan kebebasan kepada anak untuk memilih dan melakukan suatu tindakan.

Dengan demikian dapat ditarik suatu kesimpulan bahwa dalam pola asuh authoritative ini anak diberi kebebasan dan tanggung jawab dengan maksud anak tetap dalam pengawasan orang tua dan perbuatan anak dapat dipertanggung jawabkan secara moral. Pola asuh authoritative dapat menjadikan anak sebagai seorang individu yang mempercayai seseorang, bertanggung jawab atas tindakannya, tidak munafik, jujur.

\section{B. Anak Usia Dini}

Anak usia dini adalah anak-anak yang berkisar pada usia dibawah delapan tahun dengan pribadi yang menakjubkan. Anak usia dini menurut Undang-Undang No 20 Tahun 2003 tentang Sistem Pendidikan Nasional, ialah anak sejak lahir sampai usia enam tahun (Santoso, 2005:1.2)

Hal ini sejalan dengan pendapat Mutiah (2010:6-7) yang menyatakan bahwa "anak usia dini adalah kelompok anak yang berada dalam proses pertumbuhan dan perkembangan yang bersifat unik", artinya memiliki pola pertumbuhan dan perkembangan meliputi fisik (koordinasi motorik kasar-halus), kecerdasan (daya fikir dan daya cipta), sosial emosoinal, bahasa dan komunikasi.

Prayitno (2010:3) menyatakan "anak usia dini adalah peribadi yang menakjubkan yang ingin mencapai banyak hal sekaligus. Perkembangan psikologi, sosial dan kognitif, anak berinteraksi serta bergantung pada kemampuanya untuk menguasai keterampilan motorik dan bahasanya". Masa kanak-kanak adalah masa pembentukan fondasi dan dasar kepribadian yang akan menentukan pengalaman anak selanjutnya.

Berdasarkan keunikan dalam pertumbuhan dan perkembangannya, anak usia dini terbagi dalam tiga tahapan, yaitu (1) masa bayi lahir sampai 12 bulan, (2) masa toddler (batita) usia 1-3 tahun, (3) masa prasekolah usia 3-6 tahun, (4) masa kelas awal SD 6-8 tahun. Pertumbuhan dan perkembangan anak usia dini perlu diarahkan pada peletakan dasardasar yang tepat bagi pertumbuhan dan perkembangan manusia seutuhnya, yaitu pertumbuhan dan perkembangan fisik, daya pikir, daya cipta, sosial emosional, bahasa dan komunikasi yang seimbang sebagai dasar pembentukan pribadi yang utuh.

Masa keemasan anak usia dini adalah merupakan masa tumbuh kembang kecerdasan otak yang sangat bagus bagi proses perkembangan dirinya dengan memberikan arahan dan bimbingan kepada anak usia dini untuk membantu pengenalan jati diri yang sesunguhnya yang berhubungan dengan kemapuan diri. Pada rentan usia lahir sampai 6 tahun anak mengalami masa keemasan (the golden age) yang merupakan masa dimana anak mulai peka/ sensitifi untuk menerima berbagai rangsangan.

Pendidikan bagi anak usia dini adalah pemberian upaya untuk menstimulasi, membimbing, mengasuh dan pemberian kegiatan pembelajaran yang akan menghasilkan kemampuan dan keterampilan anak. Pendidikan bagi anak usia dini merupakan sebuah pendidikan yang dilakukan pada anak yang baru lahir sampai dengan delapan tahun. Pendidikan pada tahap ini memfokuskan pada physical, intelligence, emotional, social education.

Pendidikan anak usia dini memegang peranan yang sangat penting dan menentukan bagi sejarah perkembangan anak selanjutnya, sebab pendidikan anak usia dini merupakan fondasi bagi dasar kepribadian anak. Anak yang mendapatkan pembinaan sejak usia dini akan dapat meningkatkan kesehatan dan kesejahteraan fisik dan mental, yang itu akan bedampak pada peningkatan hasil belajarnya. Dengan demikian anak akan lebih mampu untuk mandiri dan mengoptimalkan potensi yang dimilikinya.

Tujuan pendidikan anak usia dini adalah untuk meletakkan dasar-dasar pengembangan perilaku, pengetahuan, keterampilan dan daya cipta anak sehingga semua potensi yang dimiliki anak dapat berkembang secara maksimal. Hal ini sejalan dengan pendapat Suyanto (2005:5) yang menyatakan bahwa pendidikan anak usia dini bertujuan untuk mengembangkan seluruh potensi anak (the whole child) agar kelak dapat berfungsi sebagai manusia yang utuh sesuai falsafah suatu bangsa. Untuk itu, dalam mencapai tujuan itu orang tua dan guru perlu memahami kemampuan-kemampuan yang harus dikuasai oleh anak.

Berdasarkan pendapat para ahli diatas maka dapat di tarik suatu kesimpulan bahwa anak usia dini adalah sekelompok anak yang berada pada rentang usia 0-6 tahun yang mengalami pertumbuhan dan perkembangan yang pesat yang bersifat unik dan memiliki pribadi yang menakjubkan serta bergantung pada kemampuanya untuk menguasai perkembangannya. 
Website : http://sosial.unmermadiun.ac.id/index.php/sosial

\section{Tenaga Kerja Wanita}

Tenaga Kerja Indonesia (disingkat TKI) adalah sebutan bagi warga negara Indonesia yang lowlife dan unskill yang bekerja di luar negeri (seperti Malaysia, Timur Tengah, Taiwan, Uganda dan Somalia) dalam hubungan kerja untuk jangka waktu tertentu dengan menerima upah.

Adapun pengertian Tenaga Kerja Indonesia (TKI) adalah orang-orang yang berkewargaan negara Indonesia baik laki-laki ataupun perempuan yang melakukan pekerjaan keluar negara. Dengan kata lain Tenaga Kerja Indonesia adalah orang-orang Indonesia yang bekerja keluar negara Indonesia. Tenaga kerja dan buruh bekerja ikut orang lain yang disebut dengan majikan. Pengertian majikan berlawanan dengan buruh atau tenaga kerja. Majikan mempunyai arti yang sama dengan pengusaha (Djulmiadji, 2001:26).

Namun, istilah TKI seringkali dikonotasikan dengan pekerja kasar karena TKI sejatinya memang adalah kumpulan tenaga kerja unskill yang merupakan program pemerintah untuk menekan angka pengangguran. TKI perempuan seringkali disebut Tenaga Kerja Wanita (TKW). Jumlah pengiriman TKW dari tahun ke tahun mengalami peningkatan seiring dengan pertambahan jumlah penduduk di Indonesia.

Menurut Nawawi (2007:9) Tenaga Kerja Wanita (TKW) adalah seorang wanita yang bekerja di luar negeri, baik sebagai pembantu rumah tangga ataupun sebagai buruh perusahaan. Para wanita rela menajdi TKW karena tuntutan kebutuhan hidup yang makin meningkat sehingga para orang tua berusaha mencari pekerjaan dengan penghasilan yang layak hingga mereka menjadi TKW. Ibu yang menjadi TKW ini harus rela berpisah jauh sementara dengan anak, keluarga dan kerabat lainnya dan hal ini akan baik bagi keluarga, karena dengan bekerja dan berpenghasilan yang layak akan meningkatkan kesejatraan keluarga yang ditinggalkannya.

Disisi lain, ibu yang menjadi TKW adalah sosok orang yang mempunyai peranan penting bagi kehidupan dan tumbuh kembang anak usia dini. Untuk itu ibu adalah orang yang harus memberikan perhatian dan kasih saying kepada anak-anak sepenuh hati. Dengan menjadi seorang TKW maka sosok ibu tidak dapat memberikan perhatian secara penuh kepada anaknya karena keterbatasan jarak dan waktu. Anak akan kehilangan sosok ibu yang biasanya membimbing dan mengarahkan anaknya dalam hal pendidikan. Oleh karena itu orang tua yang menjadi TKW harus pandai-pandai memilih cara yang tepat untuk tetap memberi perhatian terhadap perkembangan pendidikan anak yang ditinggalkan.

\section{III.METODE PENELITIAN}

Penelitian ini menggunakan metode penelitian deskriptif kualitatif yang merupakan upaya memahami berbagai konsep yang ditemukan dalam proses penelitian. Metode deskriptif kualitatif ini merupakan pilihan yang paling menguntungkan untuk membaca proses perubahan situasi social.

Pengumpulan data dalam penelitian ini menggunakan tiga cara meliputi pengamatan (observasi), indepth interview (wawancara mendalam), dan dokumentasi.

Teknik analisis data dalam penelitian ini menggunakan model interaktif. Menurut Moleong (2000:118) menjelaskan bahwa: dalam melakukan proses analisis komponen utama yang perlu diperhatikan setelah pengumpulan data adalah :

1. Reduksi data, yaitu proses pemilihan, penyederhanaan, pengabstrakan dan transformasi data kasar dari catatan-catatan tertulis di lapangan hingga laporan akhir lengkap tersusun.

2. Penyajian data, yaitu sekumpulan informasi yang tersusun agar dapat memberi kemungkinan dapat menarik kesimpulan. Dalam penyajian data ini dilakukan setelah melakukan reduksi data yang akan dipergunakan sebagai bahan laporan.

3. Menarik kesimpulan atau verifikasi, yaitu berupa intisari dari penyajian data yang merupakan hasil dari analisis yang dilakukan dalam penelitian.

Ketiga komponen ini merupakan satu kesatuan yang utuh dan saling terkait, artinya analisis ini dilakukan dalam bentuk interaksi pada tiga komponen tersebut.

\section{IV.HASIL PENELITIAN DAN PEMBAHASAN}

Berdasarkan hasil observasi, wawancara serta berdasarkan dokumentasi dapat diperoleh hasil penelitian sebagai berikut:

\section{A. Pola Asuh Autoritave Anak Usia Dini Yang Memiliki Ibu Tenaga Kerja Wanita Di TK Bajang Mlarak Ponorogo}

Pola asuh adalah cara orang tua dalam mendidik anaknya. Setiap orang memiliki berbagai macam cara yang berbeda dalam mendidik atau mengarahkan anaknya. Pola asuh yang salah dapat mengakibatkan fatalnya perkembangan anak. Dalam mendidik anak, ibu TKW harus bisa memilih pola asuh yang tepat untuk perkembangan anaknya. Hal ini dikarenakan ibu TKW tidak bisa memantau secara langsung perkembangan anaknya setiap saat.

Berdasarkan hasil wawancara dengan pengasuh siswa yang ibunya bekerja menjadi TKW dapat diketahui bahwa pengasuh pengganti memberikan kebebasan anak untuk dapat belajar secara mandiri namun masih tetap dalam pantauan dari pengasuh pengganti. Misalnya tidak mengekang waktu anak, jadi pengasuh pengganti tetap membiarkan anak-anak bermain bersama temannya ketika saatnya bermain. Pengasuh pengganti juga selalu mendukung keinginan anak selama masih dalam hal yang positif. Pola pengasuhan demikian merupakan bentuk pola asuh autoritatif sebagaimana yang disampaikan Baumrind (dalam Santrock 2002: 257-258) bahwa pola asuh autoritatif atau demokrasi, pada pola asuh ini orang tua yang mendorong anakanaknya agar mandiri namun masih memberikan batas-batas dan pengendalian atas tindakan-tindakan mereka. 
Pola asuh autoritatif dalam bentuk lain yang di lakukan pengasuh pengganti di TK Bajang Mlarak Ponorogo yang memiliki ibu TKW adalah dalam kegiatan belajar, pengasuh pengganti juga memberikan bimbingan dalam belajar dengan menemani anak untuk belajar sehingga proses belajar tidak membosankan bagi anak. Di samping itu pengasuh pengganti juga memberikan kebebasan kepada anak dalam memilih dan melakukan suatu tindakan.

Ketika anak melakukan suatu kesalahan, pengasuh pengganti tetap memberikan suatu hukuman kepada anak disertai dengan penjelasan atas kesalahannya tersebut. Hukuman yang diberikanpun tidak bersifat menyakiti secara fisik namun lebih bersifat mendidik. Misalnya saja anak disuruh menghafalkan surat pendek, dsb. Dengan demikian anak akan lebih bertanggungjawab atas segala tindakan yang dilakukannya.

Seorang anak akan dapat tumbuh dan berkembang dibawah asuhan dan pembinaan dari orang tua. Anak akan meniru, memahami dan melakukan norma-norma yang ada di lingkungan keluarga mereka. Norma-norma yang ada dalam suatu keluarga merupakan ciptaan dari orang tua mereka yang merupakan alat untuk mengarahkan dan membentuk kepribadian dan perilaku anak mereka yang digunakan sebagai batasan dalam kehidupan sehari-hari mereka, menentukan hal-hal apa yang boleh mereka kerjakan atau hal-hal yang dilarang oleh orang tua mereka, baik itu orang tua asli maupun orang tua pengganti.

Berdasarkan hasil wawancara dengan guru, pola asuh autoritatif selain di terapkan oleh pengasuh pengganti juga di lakukan oleh ibunya sendiri dari jarak jauh seperti pada proses pemantauan dari ibu TKW lewat komunikasi secara intensif dengan guru dan anaknya secara langsung melalui handphone. Orang tua sering mengontrol perkembangan belajar anaknya dan sikap atau perilaku anaknya selama berada di sekolah. Di dalam pola asuh ini juga terjadi komunikasi dua arah antara anak dan orang tua sehingga anak merasakan ada perhatian dari ibunya yang menjadi TKW.

Dengan demikian dapat disimpulkan bahwa anak yang memiliki ibu TKW tetap mendapatkan pola pengasuhan yang baik dari pengasuh pengganti maupun dari ibu TKW dengan pengasuhan secara autoritative seperti tidak mengekang kebebasan anak untuk bermain dan belajar serta memberikan kebebasan dalam bertindak selama bersifat positif.

\section{B. Hasil Belajar Anak Usia Dini Yang Memiliki Ibu Tenaga Kerja Wanita dengan Pola Asuh Autoritatif Di TK Bajang Mlarak Ponorogo}

Pendidikan anak merupakan dasar sebagai bekal kehidupannya agar menjadi lebih baik. Pendidikan anak mencakup tiga aspek yaitu kognitif, afektif dan psikomotoriknya. Pendidikan anak sangat dipengaruhi sekali oleh pola pengasuhan yang diberikan oleh orang tua.

Orang tua yang memberikan pengasuhan secara benar akan berdampak positif bagi hasil belajarnya di sekolah. Berdasarkan hasil wawancara dengan guru di TK Bajang Mlarak Ponorogo dapat diketahui bahwa hasil belajar anak-anak yang memiliki ibu TKW tidak kalah dengan anak-anak yang diasuh oleh ibu yang bukan TKW. Hal ini disebabkan meskipun ibunya menjadi TKW namun pengasuh pengganti mampu memberikan pola pengasuhan secara autoritative kepada anak sehingga anak dapat mengoptimalkan potensi dirinya sehingga hasil belajarnya dapat berkembang dengan baik.

Hal ini dibuktikan dengan hasil belajar anaknya disekolah dimana dalam nilai-nilai agama, sosial, emosional dan kemandirian dapat berkembang dengan baik. Dalam bersosialisasi dengan kawanya dan dalam pengembangan nilai agamanya sudah terlihat dari tingkah lakunya sehari-hari dengan sopan dan baik serta lancar terhadap bacaan surat-surat pendek. Kemampuan dasar dalam pengembangan bahasanya juga baik dengan mengucap dan menjawab pertanyaan sudah mulai berkembang sesuai harapan. Pengembangan bahasa baik dalam menulis huruf.

Untuk kognitifnya sudah dapat mengenal konsep bilangan, pengelompokan benda berdasarkan jenis ukuran dengan baik, mulai menyukai penjumlahan dan pengurangan bilangan dan menyelesaikan tugas dengan baik. Untuk perkembangan motoriknya meliputi motorik kasar, halus dan kesehatan fisiknya dapat berkembang dengan baik.

Sementara untuk perkembangan nilai-nilai moral dan sosial emosionalnya, anak sudah mempunyai rasa tanggung jawab terhadap tugas-tugas yang diberikan. Anak sudah bisa memahami sikap toleransi, dan belajar mengontrol emosi.

Dengan demikian dapat ditarik suatu kesimpulan bahwa hasil belajar anak yang memiliki ibu TKW di TK Bajang Mlarak Ponorogo berkembang dengan baik,ss baik dalam aspek kognitif, afektif dan psikomotornya. Pola asuh orang tua yang diterapkan pada anak yang mencerminkan hubungan keluarga yang sehat dan bahagia menimbulkan dorongan untuk berprestasi pada anak sehingga anak mampu meraih hasil belajar yang maksimal.

\section{KESIMPULAN}

1. Anak yang memiliki ibu TKW tetap mendapatkan pola pengasuhan yang baik dari pengasuh pengganti maupun dari ibu TKW dengan pengasuhan secara autoritative seperti tidak mengekang kebebasan anak untuk bermain dan belajar serta memberikan kebebasan dalam bertindak selama bersifat positif.

2. Hasil belajar anak yang memiliki ibu TKW di TK Bajang Mlarak Ponorogo berkembang dengan baik baik dalam aspek kognitif, afektif dan psikomotornya. 
Website : http://sosial.unmermadiun.ac.id/index.php/sosial

\section{VI.DAFTAR PUSTAKA}

Djulmiadji, F.X.. 2001. Perjanjian Kerja. Jakarta: Bumi Aksara.

Euis, Sunarti.2004. Mengasuh Anak dengan Hati. Jakarta: PT Elex Media Komputindo.

Gunarsa, Singgih D. 2008. Psikologi Perkembangan Anak dan Remaja. Jakarta: Gunung Mulia.

Imam Nawawi. 2007. Peran Ayah terhadap Pendidikan Keagamaan Anak; Studi Deskriptif pada Keluarga TKW di Desa Demangsari Kecamatan Ayah. (Skripsi tidak diterbitkan).

Kayo, Khatib Pahlawan. 2005. Kepemimpinan Islam dan Dakwah. Jakarta: Amzah.

Lexi Moleong. 2000. Metodologi Penelitian Kualitatif. Bandung: Rosdakarya.

Mutiah, Diana. 2010. Psikologi Bermain Anak Usia Dini. Jakarta: Kencana Pernada Media Group.

Prayitno, Irwan. 2010. Anakku penyejuk Hatiku. Jakarta: Pustaka Tarbiatuna.

Santoso. 2005. Perkembangan Anak Usia Dini. Jakarta : Prenada Media Group.

Santrock, Jhon. 2002. Perkembangan Masa Hidup Edisi ke-5 Jilid 1. Jakarta: Erlangga.

Suyanto, Slamet. 2005. Konsep Dasar Pendidikan Anak Usia Dini. Jakarta: Dirjen Dikti.

Undang-Undang Dasar Negara Republik Indonesia Nomor 20 Tahun 2003 Tentang Sistem Pendidikan Nasional. Jakarta: Sinar Grafika.

Yanti. 2005. Pola Asuh Orantua terhadap Perilaku Sosial Anak. Skripsi. Universitas Gunadarma. 